\title{
INDUKSI KALUS CENGKEH DARI EKSPAN DAUN MENGGUNAKAN 2,4-D SECARA IN VITRO
}

\author{
Yulianti Rasud ${ }^{1}$, Zainuddin Basri ${ }^{2}$, Nirwan Sahiri ${ }^{3}$ \\ 1,2,3 Sekolah Tinggi Ilmu Pertanian Mujahidin Tolitoli \\ Jl. DR. Sam Ratulangi No. 51 Tolitoli Sulawesi Tengah (94515) \\ Email : yulirasud.stip@gmail.com
}

Received: 16 July 2019 Accepted: 25 September 2019

\begin{abstract}
Callus induction is one method of tissue culture which is done by stimulating cell division continuously from certain plant parts such as leaves, roots, stems, and so on by using growth regulators to form cell mass. The cell mass (callus) will then regenerate through organogenesis or embryogenesis to become a new plant. One of the growth regulators used for callus induction is 2,4-D. The aims of this experiments was to evaluate the best concentration of 2,4-D for callus induction of clove leaves. The experiment used Completely Randomized Design with treatment tested was concentrations of 2,4-D, consisted of six levels, namely $0.5 \mathrm{ppm}, 1.0 \mathrm{ppm}, 1.5 \mathrm{ppm}, 2.0$ ppm, $2.5 \mathrm{ppm}$ and $3.0 \mathrm{ppm}$. Results of this experiments indicated that the best medium composition for callus induction was MS medium supplemented with $0.5 \mathrm{ppm}$ 2,4-D. In the medium composition, the fastest callus formation, namely 6.00 weeks after culture and the percentage of callus formation reached $100 \%$ with the color and texture of the resulting callus white and crumb.
\end{abstract}

Keyword : Callus Induction, Clove, 2,4-D

\section{ABSTRAK}

Induksi kalus merupakan salah satu metode kultur jaringan yang dilakukan dengan jalan memacu pembelahan sel secara terus menerus dari bagian tanaman tertentu seperti daun, akar, batang, dan sebagainya dengan menggunakan zat pengatur tumbuh hingga terbentuk massa sel. Massa sel (kalus) tersebut selanjutnya akan beregenerasi melalui organogenesis ataupun embriogenesis hingga menjadi tanaman baru. Salah satu zat pengatur tumbuh yang digunakan untuk induksi kalus adalah 2,4-D. Penelitian ini bertujuan menentukan konsentrasi 2,4D yang lebih baik untuk induksi kalus daun cengkeh. Penelitian ini menggunakan Rancangan Acak Lengkap (RAL) dengan tiga kali ulangan. Media dasar yang digunakan adalah media MS yang ditambahkan berbagai konsentrasi 2,4-D yaitu 0,50 ppm, 1,5 ppm, 2 ppm, 2,5 ppm, dan $3 \mathrm{ppm}$. Hasil penelitian menunjukkan bahwa komposisi media yang terbaik untuk induksi kalus daun cengkeh adalah media MS yang ditambahkan 0,5 ppm 2,4-D. Pada komposisi media tersebut diperoleh saat muncul kalus paling cepat, yaitu rata-rata 6,00 MST dengan persentase pembentukan kalus tertinggi mencapai $100 \%$ dengan warna dan tekstur kalus yang dihasilkan putih dan remah.

Kata Kunci : Induksi Kalus, Cengkeh, 2,4-D.

\section{PENDAHULUAN}

Cengkeh merupakan salah satu komoditas perkebunan andalan Nasional yang memiliki nilai ekonomi tinggi dan banyak digunakan dalam bidang industri utamanya sebagai bahan baku pembuatan rokok kretek. Selain itu cengkeh juga dapat dimanfaatkan sebagai bahan obat-obatan, kosmetik , sebagai hiasan yang memiliki nilai seni yang tinggi serta sebagai penyediaan lapangan kerja, sumber pendapatan petani dan sumber devisa bagi negara. Mengingat kebutuhan cengkeh Nasional dari tahun ke tahun semakin meningkat oleh karena itu diperlukan upaya dalam peningkatan produksi tanaman cengkeh. Saat ini produksi cengkeh di Indonesia mengalami fluktuatif. Berdasarkan data Badan Pusat Statistik (2018), untuk periode Januari-November, ekspor cengkeh dari Indonesia baru mencapai US\$ 76,97 juta, sehingga Indonesia masih mengimpor cengkeh dari Madagaskar, Tanzania dan Komoro. Salah satu penyebab Indonesia masih mengimpor cengkeh dari negara luar dikarenakan rendahnya produksi dan produktivitas cengkeh.

Rendahnya produktivitas ini disebabkan beberapa faktor, diantaranya umur tanaman yang sudah tua, pemeliharaan yang kurang memadai, perakaran yang sudah tidak mampu menembus solum tanah, serangan hama dan penyakit, bibit 
tidak seragam, serta masih kurangnya varietas unggul. Umumnya, bibit cengkeh diperbanyak dengan cara konvensional melalui biji sehingga dibutuhkan waktu yang lebih lama untuk menghasilkan bibit dalam jumlah yang besar. Untuk mengatasi masalah tersebut dapat ditempuh melalui aplikasi kultur jaringan. Beberapa teknik kultur jaringan antara lain yaitu fusi protoplas, keragaman somaklonal, seleksi in vitro dan transformasi genetik, dimana langkah awal dari semua kegiatan tersebut adalah menginduksi kalus yang bersifat embrionik. Induksi kalus dilakukan dengan jalan memacu pembelahan sel secara terus menerus dari bagian tanaman tertentu seperti daun, akar, batang, dan sebagainya dengan menggunakan zat pengatur tumbuh hingga terbentuk massa sel. Massa sel (kalus) tersebut selanjutnya akan beregenerasi melalui organogenesis ataupun embriogenesis hingga menjadi tanaman lengkap (Bustami, 2011).

Keberhasilan pelaksanaan kultur jaringan ditentukan oleh beberapa faktor antara lain komposisi zat pengatur tumbuh, sumber eksplan dan jenis tanaman. Zat pengatur tumbuh berguna untuk menstimulasi pembentukan kalus dan organ tanaman. Salah satu zat pengatur tumbuh yang umum digunakan dalam menginduksi kalus adalah 2,4-D. 2,4-D efektif untuk merangsang pembentukan kalus karena aktivitas yang kuat untuk memacu proses diferensiasi sel, organogenesis dan menjaga pertumbuhan kalus (Sitinjak et al., 2015). Penggunaan 2,4-D dalam menginduksi kalus tanaman cengkeh hingga saat ini belum pernah dilaporkan, namun penggunaan 2,4-D pada media kultur jaringan pada tanaman lain telah banyak dilaporkan, diantaranya Avivi et al., (2010), menyatakan penambahan 2,4-D pada media MS dapat menstimulasi pembentukan kalus dari eksplan staminodia bunga kakao klon Sca 6. Arianto et al., (2013), melaporkan penggunaan 2,4-D pada konsentrasi 1 ppm baik pada klon Sulawesi 1 maupun klon Sulawesi 2 merupakan konsentrasi yang lebih baik untuk menginduksi kalus dengan persentase pembentukan kalus mencapai $100 \%$. Selanjutnya, Rasud et al., (2019) menyatakan kemampuan induksi kalus berbeda pada berbagai konsentrasi 2,4-D untuk klon kakao unggul Sulawesi 1 yang dicobakan. Saat muncul kalus paling cepat diperoleh pada konsentrasi $0,5 \mathrm{ppm}$ 2,4-D yaitu rata-rata 16,67 HST dengan persentase pembentukan kalus tertinggi mencapai 99,33\%. Warna dan tekstur kalus yang dihasilkan yaitu remah putih dan remah kecoklatan. Tujuan penelitian ini adalah untuk menentukan konsentrasi 2,4-D yang lebih baik untuk induksi kalus daun cengkeh.

\section{Lokasi Penelitian}

Penelitian ini dilaksanakan di Laboratorium Bioteknologi Tanaman, Fakultas Pertanian Universitas Tadulako Palu pada bulan Juni 2011 hingga April 2012.

\section{Desain Penelitian}

Penelitian ini menggunakan Rancangan Acak Lengkap (RAL) dengan perlakuan yang dicobakan konsentrasi 2,4-D yang dari lima level, yaitu : 0,50 ppm, 1,5 ppm, 2 ppm, 2,5 ppm, dan $3 \mathrm{ppm}$. Setiap perlakuan diulang sebanyak tiga kali sehingga terdapat 15 unit percobaan. Tiap unit percobaan menggunakan 5 eksplan, dengan demikian terdapat total 90 eksplan. Guna mengetahui pengaruh perlakuan yang dicobakan, data yang diperoleh dianalisis menggunakan analisis ragam. Hasil analisis ragam yang menunjukkan pengaruh nyata atau sangat nyata, dilanjutkan menggunakan uji DMRT pada taraf $1 \%$.

\section{Alat dan Bahan Penelitian}

Peralatan yang digunakan pada penelitian ini adalah batang pengaduk, gelas stainless, pemanas listrik (hot plate), magnetic stirrer, destilasi air, timbangan analitik, corong, gelas ukur, kelas kimia, Erlenmeyer, pipet, autoclave, oven listrik, handspayer, cawan Petri, lampu Bunsen, gunting, pinset, scalpel, blade, rotary shaker, $p H$ meter, Laminar air flow cabinet dan parafilm. Eksplan yang digunakan adalah daun cengkeh, Bahan lain yang digunakan yaitu bahan kimia sesuai komposisi media MS (Murashige dan Skoog), glukosa, phytagel, zat pengatur tumbuh 2,4-D, alkohol 70\%, aquades steril, chlorox, detergen, spritus, tissue dan kertas label.

\section{Pelaksanaan Penelitian}

Pelaksanaan penelitian ini meliputi kegiatan sterilisasi alat dan aquades, pembuatan dan strerilisasi media, sterilisasi bahan tanaman, penanaman dan pemeliharaan. Seluruh peralatan yang akan digunakan terlebih dahulu disterilkan untuk menghindari terjadinya kontaminasi. Alatalat yang digunakan dicuci terlebih dahulu dengan detergen, dibilas, kemudian dikeringkan. Setelah kering, alat-alat seperti cawan Petri, corong, gelas ukur, scalpel, pinset, batang pengaduk dan pipet dibungkus rapi dengan kertas. Kemudian seluruh alat tersebut disterilkan 
dengan menggunakan autoklaf pada suhu $121^{\circ} \mathrm{C}$ dan tekanan 17,5 psi selama satu jam. Hal ini juga berlaku untuk sterilisasi aquades, yaitu menggunakan suhu dan tekanan yang sama.

Langkah awal dalam pembuatan media adalah pembuatan larutan stok. Larutan stok dibuat sesuai komposisi media MS. Pembuatan media dimulai dengan mengambil larutan stok media MS sesuai dengan takaran, kemudian larutan tersebut dimasukkan ke dalam labu takar kapasitas 1L. Setelah semua komponen larutan stok dimasukkan ke dalam labu takar, kemudian ditambahkan $30 \mathrm{~g}$ sukrosa dan dicampurkan dengan zat pengatur tumbuh sesuai perlakuan. Selanjutnya, ditambahkan aquades hingga volume larutan mencapai 1 liter. Seluruh media ditetapkan $\mathrm{pH} 5,8$. Media tersebut selanjutnya dipanaskan menggunakan hot plate pada suhu sekitar $800^{\circ} \mathrm{C}$ setelah ditambahkan 8 gram agar. Sambil dipanaskan, larutan media tersebut diaduk hingga semua agar terlarut. Pemanasan dihentikan saat media menjadi bening. Media kemudian dituang ke botol kultur dengan volume $25 \mathrm{ml}$ per botol. Botol tersebut ditutup rapat dengan almunium foil/plastik dan dilabel, lalu disterilisasi dalam autoklaf pada tekanan 17,5 psi selama 15 menit.

Eksplan yang di gunakan adalah daun cengkeh tidak terlalu muda dan tidak terlalu tua. Eksplan yang telah disterilisasi selanjutnya diletakkan dalam cawan petri. Eksplan tersebut kemudian dipotong-potong dengan ukuran kurang lebih $2 \times 1 \mathrm{~cm}$, kemudian ditanam pada media induksi kalus. Setelah melakukan penanaman, semua botol kultur ditutup dengan tutup plastik lalu diketatkan dengan karet gelang dan diberi label sesuai perlakuan. Seluruh kegiatan penanaman dilakukan di dekat lampu bunsen dalam Laminar Air Flow Cabinet. Setelah selesai melakukan penanaman, semua botol kultur diletakkan pada rak kultur dalam ruang pemeliharaan gelap. Ruang pemeliharaan harus selalu steril dan dijaga kebersihannya. Suhu ruangan dipertahankan antara $22^{\circ} \mathrm{C}$ sampai $26^{\circ} \mathrm{C}$. Peubah yang diamati meliputi saat muncul kalus, jumlah eksplan membentuk kalus persentase pembentukan kalus serta pengamatan secara visual yaitu warna dan tekstur kalus.

\section{HASIL DAN PEMBAHASAN Saat Muncul Kalus}

Hasil analisis ragam menunjukkan bahwa masing-masing perlakuan 2,4-D yang dicobakan berpengaruh sangat nyata terhadap saat muncul kalus. Rata- rata saat muncul kalus dari berbagai perlakuan yang dicobakan disajikan pada Tabel 1 .

Tabel 1. Saat Munculnya Kalus dalam Hari Setelah Tanam (HST)

\begin{tabular}{ccc}
\hline Perlakuan & $\begin{array}{l}\text { Rata-rata } \\
\text { (MST) }\end{array}$ & DMRT 1\% \\
\hline 0,5 ppm 2,4-D & $6,00 \mathrm{a}$ & - \\
1,0 ppm 2,4-D & $6,00 \mathrm{a}$ & 1,31 \\
1,5 ppm 2,4-D & $6,33 \mathrm{a}$ & 1,38 \\
2,0 ppm 2,4-D & $6,67 \mathrm{a}$ & 1,42 \\
2,5 ppm 2,4-D & $10,67 \mathrm{~b}$ & 1,45 \\
3,0 ppm 2,4-D & $11,33 \mathrm{~b}$ & 1,46 \\
\hline
\end{tabular}

Keterangan : Angka yang ditandai huruf yang sama tidak berbeda nyata pada taraf uji DMRT $1 \%$.

Berdasarkan hasil uji DMRT 1\% pada Tabel 1, diketahui bahwa pemberian 2,4-D pada konsentrasi yang berbeda memberikan perbedaan terhadap saat muncul kalus. Pembentukan kalus pada eksplan daun cengkeh paling cepat diperoleh pada konsentrasi $0,5 \mathrm{ppm}$ dan $1 \mathrm{ppm}$ 2,4-D, yakni hanya 6,00 MST. Pembentukan kalus menjadi lebih lambat pada konsentrasi yang lebih tinggi (1,5 - 3,0 ppm 2,4-D) yakni rata-rata 6,33 - 11,33 MST.

Data pada Tabel 1 memperlihatkan bahwa rata-rata saat muncul kalus sama $(6,00$ MST) pada konsentrasi 0,5 ppm dan 1,0 ppm 2,4D. Saat muncul kalus makin lambat bila konsentrasi 2,4-D semakin meningkat (1,5 ppm 3,0 ppm 2,4-D). Berdasarkan data tersebut, maka diketahui bahwa konsentrasi 0,5 ppm dan 1,0 ppm 2,4-D merupakan konsentrasi yang sesuai untuk induksi kalus pada eksplan daun cengkeh. Pada konsentrasi tersebut diperoleh suatu kesesuaian konsentrasi antara zat pengatur tumbuh yang diberikan (eksogen) dan fitohormon (endogen) dalam memacu pembelahan sel-sel pada jaringan daun tanaman cengkeh. Kalus umumnya muncul pada bagian tepi eksplan (daun) dan disusul dengan bagian tengah daun. Kalus muncul ditandai dengan membengkaknya permukaan eksplan dan terbentuknya tonjolan-tonjolan putih yang saling berjejal. Hal ini sejalan dengan yang dilaporkan Dwipayana et al., (2016), bahwa pembengkakan pada eksplan terjadi karena adanya pengaruh pemberian 2,4-D yang merupakan suatu proses pertumbuhan setelah terjadinya proses pelengkungan akibat penyerapan air dan nutrisi dari media yang selanjutnya disertai dengan tahap perbanyakan sel.

Kemunculan kalus merupakan respons terhadap pelukaan atau karena adanya pengaruh hormon tumbuh alami atau pun buatan yang 
ditambahkan ke media. Adanya pelukaan ini memudahkan 2,4-D berdifusi ke dalam jaringan tanaman. Dengan berdifusinya 2,4-D ke dalam jaringan tanaman, terutama melalui jaringan yang terluka tersebut, akan menstimulasi pembelahan sel terutama sel-sel yang berada di sekitar daerah yang terluka. Awal munculnya kalus ditandai dengan munculnya gumpalan selsel yang berwarna putih. Selanjutnya gumpalangumpalan tersebut berkembang membentuk massa sel yang disebut kalus. Robles-Martinez et al., (2016), menyatakan bahwa 2,4- D dapat memacu pertumbuhan kalus, menaikkan tekanan osmotik, meningkatkan permeabilitas sel terhadap air, menyebabkan pengurangan tekanan pada dinding sel, meningkatkan sintesis protein, meningkatkan plastisitas, dan pengembangan dinding sel. Pembentukan kalus pada media yang ditambahkan 0,5 ppm 2,4-D ditampilkan pada Gambar 1.

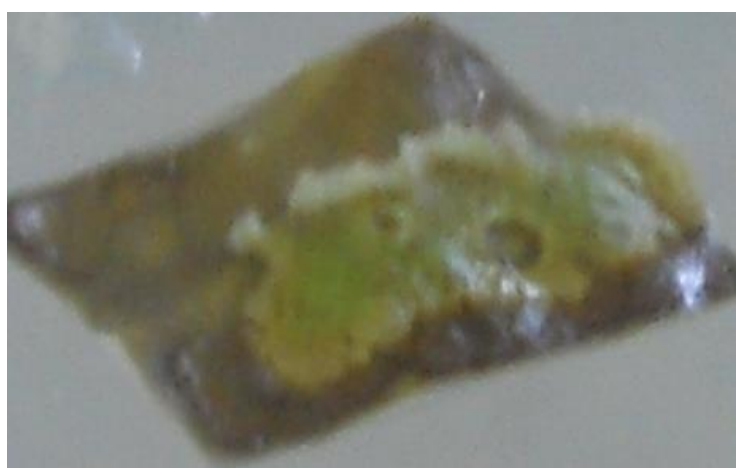

Gambar 1. Pembentukan Kalus Cengkeh pada

Pemberian 0.50 ppm 2,4-D (6 MST Jumlah Eksplan Membentuk Kalus

Hasil analisis ragam menunjukkan bahwa pemberian 2,4-D pada konsentrasi yang berbeda berpengaruh sangat nyata terhadap jumlah eksplan membentuk kalus. Rata- rata jumlah eksplan membentuk kalus dari berbagai perlakuan yang dicobakan umur 8 - 20 MST disajikan pada Tabel 2-8.

Tabel 2. Rata-rata Jumlah Eksplan Membentuk Kalus Cengkeh Umur 8-20 MST

\begin{tabular}{|c|c|c|c|c|c|c|c|}
\hline \multirow[b]{2}{*}{$\begin{array}{c}\text { Perlakua } \\
\mathbf{n}\end{array}$} & \multicolumn{7}{|c|}{ Umur Eksplan } \\
\hline & $\begin{array}{l}8 \\
\text { MST }\end{array}$ & $\begin{array}{l}10 \\
\text { MST }\end{array}$ & $\begin{array}{l}12 \\
\text { MST }\end{array}$ & $\begin{array}{l}14 \\
\text { MST }\end{array}$ & $\begin{array}{l}16 \\
\text { MST }\end{array}$ & $\begin{array}{l}18 \\
\text { MST }\end{array}$ & $\begin{array}{l}20 \\
\text { MST }\end{array}$ \\
\hline $\begin{array}{l}0,5 \mathrm{ppm} \\
2,4-\mathrm{D}\end{array}$ & $1,08^{b}$ & $0,73^{d}$ & $0,87^{\mathrm{c}}$ & $0,93^{c}$ & $0,93^{\mathrm{c}}$ & $0,93^{\mathrm{c}}$ & $1,00^{\mathrm{c}}$ \\
\hline $\begin{array}{l}1,0 \mathrm{ppm} \\
2,4-\mathrm{D}\end{array}$ & $1,14^{\mathrm{b}}$ & $0,80^{d}$ & $0,80^{\mathrm{bc}}$ & $0,87^{\mathrm{c}}$ & $0,80^{\mathrm{c}}$ & $0,80^{\mathrm{c}}$ & $0,87^{\mathrm{bc}}$ \\
\hline $\begin{array}{l}1,5 \mathrm{ppm} \\
2,4-\mathrm{D}\end{array}$ & $1,05^{\mathrm{b}}$ & $0,60^{\mathrm{cd}}$ & $0,60^{\mathrm{b}}$ & $0,80^{\mathrm{c}}$ & $0,80^{\mathrm{c}}$ & $0,80^{\mathrm{c}}$ & $0,80^{\mathrm{b}}$ \\
\hline $\begin{array}{l}2,0 \mathrm{ppm} \\
2,4-\mathrm{D}\end{array}$ & $1,05^{\mathrm{b}}$ & $0,53^{b c}$ & $0,47^{a b}$ & $0,67^{b c}$ & $0,67^{\mathrm{bc}}$ & $0,67^{b c}$ & $0,73^{\mathrm{b}}$ \\
\hline $\begin{array}{l}2,5 \mathrm{ppm} \\
2,4-\mathrm{D}\end{array}$ & $0,71^{\mathrm{a}}$ & $0,27^{a b}$ & $0,40^{a b}$ & $0,40^{\mathrm{a}}$ & $0,40^{\mathrm{a}}$ & $0,40^{\mathrm{a}}$ & $0,40^{\mathrm{a}}$ \\
\hline $\begin{array}{l}3,0 \mathrm{ppm} \\
2,4-\mathrm{D}\end{array}$ & $0,71^{\mathrm{a}}$ & $0,20^{\mathrm{a}}$ & $0,27^{\mathrm{a}}$ & $0,47^{a b}$ & $0,47^{\mathrm{ab}}$ & $0,47^{a b}$ & $0,47^{\mathrm{a}}$ \\
\hline
\end{tabular}

Keterangan : Angka yang ditandai huruf yang sama tidak berbeda nyata pada taraf DMRT $1 \%$

Sesuai hasil uji DMRT 1\% pada Tabel 28, pemberian 2,4-D pada konsentrasi yang berbeda memberikan perbedaan terhadap jumlah eksplan membentuk kalus pada minggu ke delapan hingga 20 MST. Jumlah eksplan membentuk kalus paling banyak dijumpai pada konsentrasi 0,5 ppm 2,4-D. Peningkatan konsentrasi dari 1 ppm hingga 3 ppm menyebabkan pengurangan jumlah eksplan membentuk kalus. Berdasarkan DMRT 1\%, hingga minggu kedua puluh setelah tanam pemberian 2,4-D pada konsentrasi 0,5 ppm berbeda dengan konsentrasi lainnya, tetapi tidak berbeda dengan konsentrasi 1 ppm 2,4-D. Pembentukan kalus pada media yang ditambahkan 0,5 ppm 2,4-D umur 18 MST ditampilkan pada Gambar 2

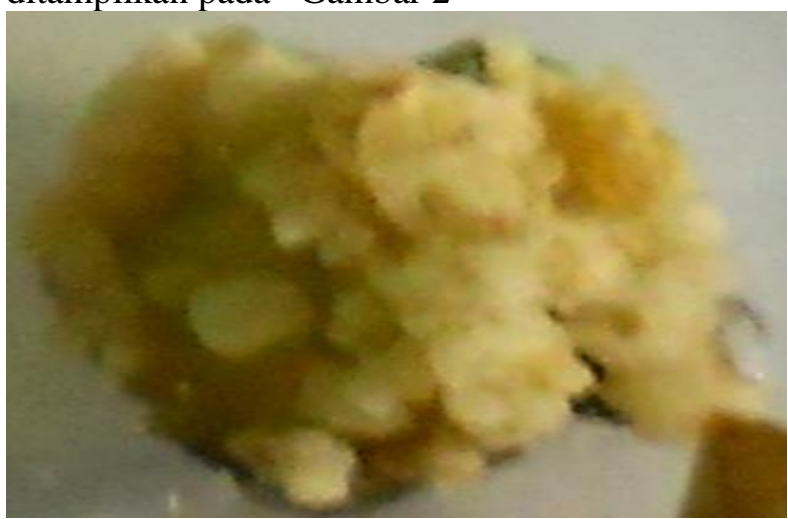

Gambar 2. Pembentukan Kalus Cengkeh pada Media yang ditambahkan 0,5 ppm 2,4-D (18 MST)

Menurut Yelnititis (2012) auksin seperti 2,4-D berperan penting dalam induksi kalus. Selain itu, auksin juga dapat menyebabkan sel yang telah mengalami diferensiasi kembali menjadi terdediferensiasi. Pertumbuhan yang terjadi pada seluruh eksplan dimungkinkan juga karena eksplan mempunyai respons yang baik terhadap komposisi media yang digunakan. Eksplan daun cengkeh yang digunakan pada percobaan ini masih muda) dan memiliki kondisi yang sehat. Eksplan yang muda (juvenil) memiliki sel-sel yang meristematis sehingga aktif melakukan pembelahan. Kesehatan eksplan juga sangat mempengaruhi kondisi fisiologis sel dan proses-proses biologis yang ada di dalamnya. Eksplan yang sehat memiliki proses fisiologis dan biologis yang baik. Chawla (2003) menyatakan bahwa eksplan yang berasal dari jaringan muda dan sehat umumnya lebih responsif dalam kultur in vitro, sehingga proses regenerasi sel dapat berlangsung cepat. 
Data pengamatan rata- rata persentase pembentukan kalus cengkeh pada berbagai perlakuan yang dicobakan hingga minggu kedua puluh disajikan pada Tabel 3 .

Tabel 3. Persentase Eksplan Berkalus (20 MST).

\begin{tabular}{cc}
\hline Perlakuan & Rata-rata (\%) \\
\hline 0,5 ppm 2,4-D & 100 \\
$0,1 \mathrm{ppm} 2,4-\mathrm{D}$ & 80 \\
$1,5 \mathrm{ppm} 2,4-\mathrm{D}$ & 60 \\
2,0 ppm 2,4-D & 53 \\
2,5 ppm 2,4-D & 13.3 \\
3,0 ppm 2,4-D & 20 \\
\hline
\end{tabular}

Indikator adanya pertumbuhan dalam kultur in vitro salah satunya ditandai dengan penambahan jumlah sel diantaranya melalui pembentukan kalus. Sesuai data yang ditampilkan pada Tabel 3 , dapat dilihat bahwa persentase pembentukan kalus dari berbagai perlakuan yang dicobakan berkisar antara 13,30\% - 100,00\%. Persentase Pembentukan kalus tertinggi diperoleh pada media yang ditambahkan 0,5 ppm 2,4-D yang mencapai 100,00\%. Persentase pembentukan kalus menurun bila konsentrasi 2,4-D semakin ditingkatkan. Hal ini sejalan dengan yang dikemukakan oleh Wijaya et al., (2017) pemberian 2,4-D pada konsentrasi yang terlalu tinggi tidak dapat mempercepat, tetapi justru akan menghambat pertumbuhan kalus dan menyebabkan toksik pada eksplan, sehingga kemampuannya dalam membentuk kalus berkurang.

2,4-D merupakan jenis auksin yang berperan dalam merangsang perbesaran sel dan sangat baik dalam pembelahan sel untuk membentuk kalus. Menurut Rahardja et al., (2012), penambahan 2,4-D dalam media akan merangsang pembelahan dan pembesaran sel pada eksplan sehingga dapat memacu pembentukan dan pertumbuhan kalus. Dari hasil yang diperoleh jelas bahwa penambahan 2,4-D $(0,5 \mathrm{ppm})$ sudah cukup untuk menstimulasi pembentukan kalus dari eksplan daun cengkeh. Hal ini sejalan dengan yang dilaporkan oleh Rasud et al., (2019) bahwa penggunaan 2,4-D pada konsentrasi 0,5 ppm menghasilkan persentase pembentukan kalus kakao klon Sulawesi 1 dari eksplan staminodia tertinggi hingga mencapai $100 \%$.

\section{Warna Kalus}

Indikator pertumbuhan eksplan pada budidaya in vitro berupa warna kalus menggambarkan penampilan visual kalus sehingga dapat diketahui tingkat keaktifan pembelahan suatu sel. Berdasarkan hasil penelitian, semua kalus yang terbentuk (6 MST) berwarna putih. Kalus yang terbentuk dan tumbuh pada minggu ke enam hingga ke delapan belas berwarna putih (Gambar 5a) dan setelah itu berubah menjadi putih kekuningan (Gambar 5b). Selanjutnya, warna kalus berubah menjadi kuning kecoklatan (Gambar 5c), coklat atau coklat kehitaman (Gambar 5d) pada umur 20 MST. Perubahan warna pada kalus tersebut menunjukkan adanya perubahan fase pertumbuhan pada sel, dari sel-sel yang muda dan aktif membelah (putih) menjadi sel-sel yang dewasa atau mature (putih kekuningan) dan selsel yang tua (kuning kecoklatan hingga coklat kehitaman). Perubahan warna pada kalus tersebut disebabkan oleh adanya sintesis zat-zat fenolik pada sel (kalus).

Menurut Sitinjak et al., (2015), senyawa fenolik yang terbentuk mengalami oksidasi sehingga menyebabkan warna coklat pada kalus. Kalus yang berwarna putih merupakan massa sel yang sedang aktif membelah sedangkan kalus yang berwarna putih kekuningan merupakan massa sel yang menuju fase akhir pembelahan aktif dan sel-sel yang berwarna kecoklatan merupakan massa sel yang menuju fase penuaan (senescence). Sel-sel yang demikian memiliki aktifitas pembelahan yang sangat rendah sehingga daya regenerasinya telah berkurang. Widayanto (2004), menyatakan bahwa perubahan warna pada kalus dari putih kekuningan hingga coklat mengindikasikan penurunan pertumbuhan pada sel-sel kalus. Onuoha et al (2011), menyatakan bahwa warna coklat pada eksplan disebabkan oleh oksidasi senyawa-senyawa fenolik yang menyebabkan terbentuknya senyawa-senyawa quinon yang sangat reaktif (bereaksi dengan oksigen) pada jaringan tanaman.

\section{Tekstur Kalus}

Berdasarkan hasil pengamatan secara visual terhadap tipe kalus yang terbentuk hingga dua puluh minggu setelah tanam, diperoleh tipe kalus yang bervariasi yaitu remah, kompak dan intermediet. Mahadi et al., (2016), menyatakan tekstur kalus dibedakan menjadi tiga, yaitu kalus kompak, intermediet, dan remah. Kalus yang bertekstur remah dikategorikan baik karena mudah dalam memisahkannya menjadi sel-sel tunggal pada kultur suspensi, disamping itu akan 
meningkatkan aerasi oksigen antar sel. Dengan demikian, kalus yang bertekstur remah akan memudahkan upaya perbanyakan jumlah (massa) kalus melalui kultur suspensi.

Berdasarkan hasil pengamatan secara visual, kalus remah yang terbentuk pada eksplan daun cengkeh tampak renggang, mudah dipisahkan dan jika diambil dengan pinset, kalus mudah pecah dan sebagian selnya menempel pada pinset (Gambar 5a). Widyawati (2010), menyatakan bahwa pembentukan kalus remah dipacu oleh adanya hormon auksin endogen yang diproduksi secara internal oleh eksplan yang dikultur. Pemberian 2,4-D pada konsentrasi 0,5 $1 \mathrm{ppm}$ menghasilkan kalus yang bertekstur remah dan pada konsentrasi 1,5 ppm 2,4-D menghasilkan kalus bertekstur intermediet (sebagian kompak dan sebagian remah). Kalus intermediet merupakan massa kalus yang terdiri dari kelompok sel-sel yang sebagian kompak dan lainnya remah (Widiarso, 2010). Selanjutnya, pada konsentrasi 2 hingga 3 ppm 2,4-D menghasilkan kalus yang bertekstur kompak (Gambar 5b). Terbentuknya kalus yang bertekstur kompak diduga karena tingginya konsentrasi auksin (2 - 3 ppm 2,4-D) yang diberikan sehingga mempengaruhi peningkatan konsentrasi auksin endogen. Menurut Wahyuningtyas (2014), bahwa pemberian 2,4-D pada konsentrasi tinggi ( $4 \mathrm{mg} / \mathrm{L})$ menghasilkan kalus bertekstur kompak dan berwarna putih pada akasia.

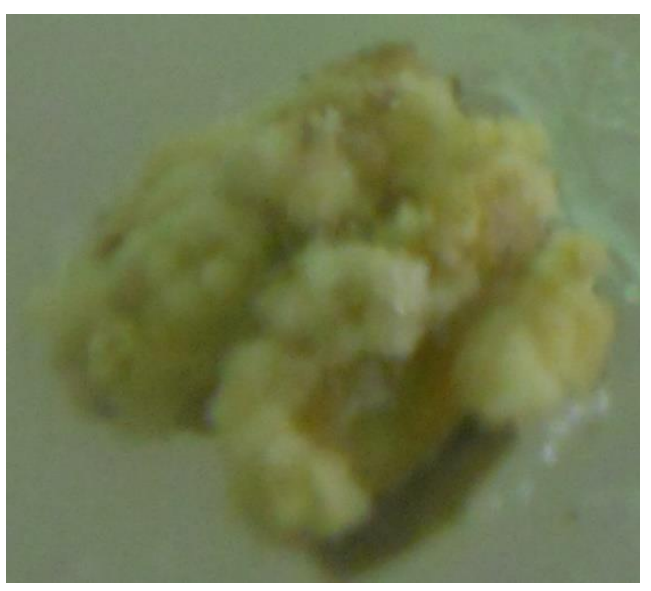

(a)

(b)
Gambar 5. Tekstur dan Warna Kalus Cengkeh pada

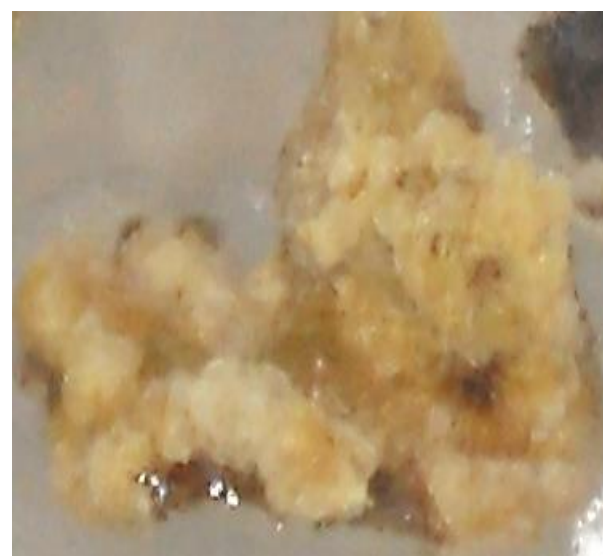

(c)
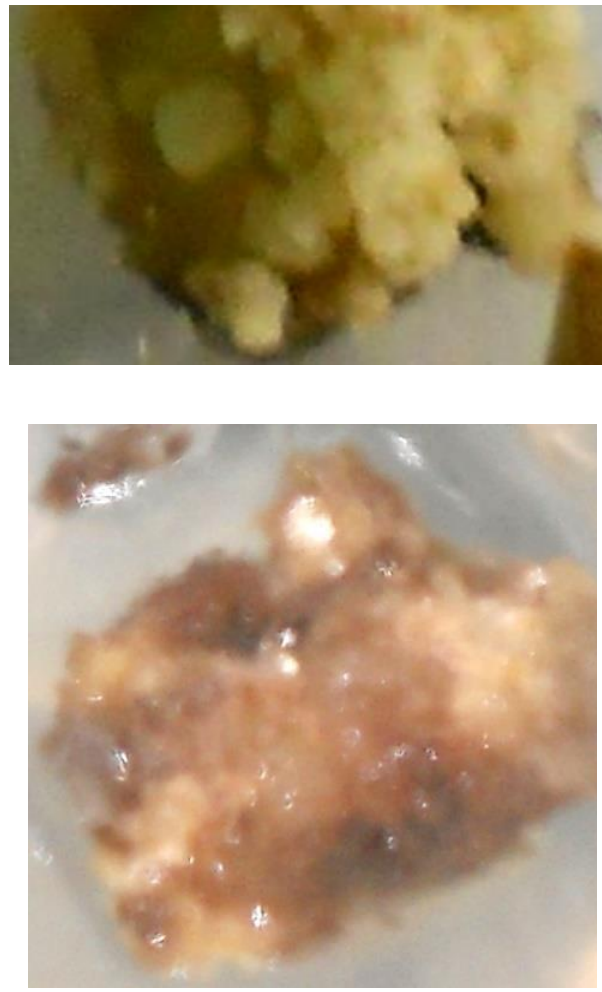

(d)

Pemberian 0,5 ppm 2,4-D

Keterangan: (a) Remah, putih (b) Kompak, putih (c) Intermediet, kuning kecoklatan (d) Intermediet, coklat

\section{KESIMPULAN}

Komposisi media yang terbaik untuk induksi kalus daun cengkeh adalah media MS yang ditambahkan 0,5 ppm 2,4-D. Pada komposisi media tersebut diperoleh saat muncul kalus paling cepat, yaitu rata-rata 6,00 MST dengan persentase pembentukan kalus tertinggi mencapai $100 \%$ dengan warna dan tekstur kalus yang dihasilkan putih dan remah.

DAFTAR PUSTAKA 
Arianto, Z. Basri dan Bustami, M.U. 2013. Induksi Kalus Dua Klon Kakao (Theobroma cacao L.) Unggul Sulawesi pada Berbagai Konsentrasi 2,4 Dichlorophenoxy Acetic acid Secara In Vitro. e-J. Agrotekbis 1 (3) : 211-220.

Avivi. S., Prawoto. A., dan Oetami, F. R., 2010 . Regenerasi Embriogenesis Somatik pada Beberapa Klon Kakao Indonesia dari Eksplan Bunga. Fakultas Pertanian, Universitas Jember, Indonesian Coffee and Cocoa Research Institute (ICCRI), Jember, Indonesia.

Badan Pusat Statistik. 2018. Indonesia dalam Angka. Indonesia.

Bustami, M.U. 2011. Penggunaan 2,4-D untuk Induksi Kalus Kacang Tanah. Media Litbang Sulteng IV (2) : 137-141.

Chawla, H. S. 2003. Plant Biotechnology Laboratory Manual for Plant Biotechnology. Oxford \& IBH Publishing. New Delhi.

Dwipayana, G.A.J., H.Yuswanti dan I.A. Mayun. 2016. Induksi Kalus Stroberi (Fragaria spp.) Melalui Aplikasi Asam 2,4Diklorofenoksiasetat Secara in vitro. EJurnal Agroekoteknologi Tropika. 5(3) : 310321.

Mahadi, I., W. Syafi'i., dan Y. Sari. 2016. Induksi Kalus Jeruk Kasturi (Citrus microcarpa) Menggunakan Hormon 2,4-D dan BAP dengan Metode in vitro. Jurnal Ilmu Pertanian Indonesia (JIPI), Vol. 21 (2).

Onuoha, I.C. 2011. Chinonye J.E and Chibuiken I.N.U. In Vitro Prevention of Browning in Plantain Culture. OnLine Jurnal of Biological Sciences II (1) : 13-17.

Rahardja, B. S., A. T. Purwitasari,. Moch., dan A. Alamsjah. 2012. Pengaruh ZPT Terhadap Pertumbuhan Nannochloropsis oculata. Jurnal Of Marine and Coastal Science. 1(2) : 71-75.

Rasud,Y., M. Habil dan Tony. 2019. Penggunaan 2,4D untuk Iinduksi Kalus Klon Kakao Unggul Sulawesi 1. J-PEN BORNEO: Jurnal Ilmu Pertanian. Volume 1, Number 1.

Robles-Martinez M, Barba-de la Rosa AP, Gueroud F, Negre-Salvayre A, Rossognol M, SantosDiaz MS. 2016. Establishment of callus and cell suspensions of wild and domesticated Opuntia Species: Study on their potential as a source of metabolite production. Plant Cell, Tissue and Organ Culture. 124(1): 181189. http://doi.org/bpqg.

Sitinjak. M.A., M. N. Isda dan S. Fatonah. 2015. Induksi Kalus dari Eksplan Daun In Vitro Keladi Tikus (Typhonium sp.) dengan Perlakuan 2,4-D dan Kinetin. Al-Kauniyah Jurnal Biologi Volume 8 Nomor 1.
Wahyuningtias. L., R.S. Resmisari dan Naschuddin. 2014. Induksi Kalus Akasia (Acacia mangium) dengan Penambahan Kombinasi 2,4-D dan BAP pada Media MS. Jurusan Biologi Fakultas Sains dan Teknologi Universitas Islam Negeri Maulana Malik Ibrahim Malang. http://etheses.uinmalang.ac.id/376/12/10620033\%20Rangku man.pdf Diakses tanggal 25 Maret 2019.

Widayanto, W. 2004. Pengaruh 2,4-D dan Kinetin terhadap Pertumbuhan dan Perkembangan Eksplan serta Kandungan Metabolit Sekunder Kalus Jati Belanda (Guazuma ulmifolia Lamk.) secara In Vitro. Skripsi tidak diterbitkan. Surakarta : Fakultas Pertanian Universitas Sebelas Maret.

Widiarso, M., 2010, Kajian Penggunaan BAP dan IBA untuk merangsang Pembentukan Tunas Lengkeng (Dimocarpus Longan Lour) Varietas Pingpong Secara In Vitro. Skripsi tidak diterbitkan, Fakultas Pertanian UNS. Surakarta.

Widyawati, G. 2010. Pengaruh Varietas Konsentrasi NAA dan BAP terhadap Induksi dan Pertumbuhan Kalus Jarak Pagar (Jatropa curcas L.). Tesis tidak diterbitkan. Surakarta : Program Pascasarjana UNS.

Wijaya, N.R., D. Suharto dan H. Sudrajad. 2017. Pengaruh BAP dan 2,4-D terhadap Inisiasi dan Pertumbuhan Kalus Pulesari (Alyxia reinwardtii Blume). Jurnal Pertanian Agros Vol. 19 No. 1 : 37-44.

Yelnititis. 2012. Pembentukan Kalus Remah dari Eksplan Daun Ramin (Gonystylus bancanus (Miq) Kurz.) Jurnal Pemuliaan Tanaman Hutan. 6(3) : $181-194$ 